\begin{tabular}{|l|l|l||}
\hline \multicolumn{2}{|c|}{ PublisherInfo } \\
\hline \hline PublisherName & $:$ & BioMed Central \\
\hline \hline PublisherLocation & $:$ & London \\
\hline \hline PublisherImprintName & $:$ & BioMed Central \\
\hline \hline
\end{tabular}

\title{
Arthritis in TNF-deficient mice
}

\begin{tabular}{|l|l|l||}
\hline \multicolumn{3}{|c||}{ ArticleInfo } \\
\hline \hline ArticleID & $:$ & 77 \\
\hline \hline ArticleDOI & $:$ & $10.1186 /$ ar-2001-68361 \\
\hline \hline ArticleCitationID & $:$ & 68361 \\
\hline \hline ArticleSequenceNumber & $:$ & 34 \\
\hline \hline ArticleCategory & $:$ & Paper Report \\
\hline \hline ArticleFirstPage & $:$ & 1 \\
\hline \hline ArticleLastPage & $:$ & 4 \\
\hline \hline & & RegistrationDate : 2001-7-27 \\
ArticleHistory & $:$ & Received \\
\hline ArticleCopyright & $:$ & Biomed Central Ltd2001-7-13 \\
\hline \hline ArticleGrants & $:$ & \\
\hline \hline ArticleContext & $:$ & 130753311 \\
\hline \hline
\end{tabular}


Aff1 Imperial College School of Medicine, London, UK

\section{Keywords}

Collagen-induced arthritis, inflammation, lymphadenopathy, mBSA/IL-1-induced arthritis, TNF

\section{Context}

Tumour necrosis factor (TNF) is thought to play a pivotal role in mediating the cytokine cascade that results in rheumatoid arthritis (RA). Although an overproduction of TNF is observed in RA and inhibition of TNF attenuates experimental arthritis, the absolute dependency of inflammatory arthritis on TNF remains to be determined. To address this issue, the authors have examined the effect of TNF deficiency in two models of RA: collagen-induced arthritis (CIA) and methylated BSA (mBSA)/IL-1-induced arthritis.

\section{Significant findings}

The overall incidence and severity of CIA in TNF-deficient mice (on a B6 background) was not significantly different compared to that in wild-type mice. Histologic analysis suggested fewer severely involved joints in the TNF-deficient mice. Importantly, some mice in both groups developed severe CIA. In the TNF-deficient mice, the IgG response to type II collagen (CII) was significantly reduced, while the IgM response was comparable to that in wild-type mice. In vitro lymph node cell proliferation was unaltered, but interferon (IFN)-? levels were significantly elevated in the knockout mice in response to CII. All TNF-deficient mice developed lymphadenopathy and splenomegaly in response to CII immunisation, with an increase in all leukocyte populations in the inguinal lymph nodes of knockout compared to wild-type mice. In particular there was a significant increase in $\mathrm{CD} 4{ }^{+}$memory $\mathrm{T}$ cells. The TNF-deficient mice also developed severe acute inflammatory arthritis in response to intra-articular mBSA injection, although the incidence of inflammatory or destructive arthritis was lower in the TNFdeficient mice compared to controls. In the synovium at day 7, levels of mRNA for IL-1a, IL-1?, IL-1 receptor antagonist, IL-18, IL-6, IFN-? and macrophage inhibitory factor differed little between knockout and wild-type animals. 


\section{Comments}

This paper demonstrates that TNF is involved in but not essential for the development of acute or chronic arthritis in mice. Given that, in the absence of TNF expression, mice can still develop severe inflammatory arthritis, the authors propose that TNF may have a biphasic effect: perhaps initially stimulating leukocyte recruitment, but later limiting inflammation by inhibiting IFN-? or mediating apoptosis of memory $\mathrm{T}$ cells. The use of a conditional TNF-deficient mouse would allow this biphasic hypothesis to be tested directly. In addition, the central role of IL-1 might have been investigated further by determining the effect of the IL-1 receptor antagonist on disease development in these TNF-deficient mice. These results do, however, provide insight into why some RA patients do not respond to anti-TNF therapy and suggest mechanisms that might explain why anti-TNF therapy may be ineffective during some phases of disease. More importantly, this model provides an opportunity for exploring in depth the TNF-independent processes which mediate inflammatory arthritis and promote disease progression in vivo.

\section{Methods}

TNF-deficient mice, ELISA, T-cell proliferation assay, immunohistochemistry, flow cytometry, RNase protection analysis, mBSA/IL-1-induced arthritis and collagen-induced arthritis models

\section{Additional information}

There are two recent commentaries on the role of anti-cytokine therapy in the treatment of arthritis.

1. Brennan F: A follow-up to "Anti-cytokine therapy in chronic destructive arthritis" by Wim B van den Berg. Arthritis Res 2001, 3:211-213 (PubMed abstract).

2. van den Berg WB: Response to Fionula Brennan's commentary "A follow-up to 'Anticytokine therapy in chronic destructive arthritis" by Wim van den Berg." Arthritis Res 2001, 3:214-215 (PubMed abstract).

And another recent paper report on the following article focuses on the roles of IL-1a and TNF in arthritis.

Niki Y, Yamada H, Seki S, Kikuchi T, Takaishi H, Toyama Y, Fujikawa K, Tada N: Macrophageand neutrophil-dominant arthritis in human IL-1a transgenic mice. J Clin Invest 2001, 107:1127-1135 (Paper report). 


\section{References}

1. Campbell IK, O'Donnell K, Lawlor KE, Wicks IP: Severe inflammatory arthritis and lymphadenopathy in the absence of TNF. J Clin Invest. 2001, 107: 1519-1527.

This PDF file was created after publication. 